\title{
МАСАЖ ТА ЛІКУВАЛЬНА ФІЗИЧНА КУЛЬТУРА ЯК ЗАСОБИ ФІЗИЧНОЇ РЕАБІЛІТАЦІї ПРИ РІЗНОВИДАХ СКОЛІОЗУ В ДОРОСЛИХ ТА ДІТЕЙ З ПОРУШЕННЯМИ ОПОРНО-РУХОВОГО АПАРАТУ
}

\author{
○Н. О. Давибіда, Д. В. Попович, Н. М. Безпалова, О. М. Довгань, \\ В. Б. Коваль, О. В. Вайда, Ю. М. Черній
}

Тернопільський національний медичний університет імені І. Я. Горбачевського МОЗ України

РЕзЮМЕ. Сколіоз призводить до розвитку анатомічних порушень. Труднощі полягають у тому, що сколіоз на ранніх стадіях розвитку захворювання може бути малопомітний, а збільшення тривалості захворювання призводить до зменшення шансів на успіх у лікуванні. Організм, намагаючись відновити вертикальний баланс хребта, утворює додаткові викривлення.

Мета - опис методик роботи з дітьми вікової групи від 9 до 16 років з набутим сколіозом 2-го ступеня та їх вплив на кінцевий результат, а саме, на різницю в ступенях деформації в градусах (на рентгенівському знімку) та візуальні зміни (за антропометричними даними).

Матеріал і методи. Використані методи діагностики та фізичної реабілітації для корекції сколіозу різного ступеня при лікуванні дітей віком 6-12 років зі вказаною патологією

Результати. При розвитку сколіозу міжхребцеві диски зазнають високого тиску з одного боку і низького - 3 іншого, внаслідок чого зміщуються у бік низького тиску, чим тільки підсилюють наявну асиметрію. Міжхребцеві диски викликають подразнення навколишніх нервових закінчень, в тому числі і вегетативних, які регулюють обмінні процеси в різних органах і тканинах організму, що призводить до розвитку кардіалгій, порушень функцій жовчного міхура тощо.

КЛючОВІ СлОВА: сколіоз; опорно-руховий апарат; фізична реабілітація; масаж.

Вступ. Сколіоз хребта - це викривлення його осі, дугоподібне за формою, що нагадує латинську букву «С» або «S». Найчастіше розвивається в період інтенсивного росту, в дітей у віці до 15 років. У дівчаток сколіоз виникає набагато частіше, ніж у хлопчиків.

Викривлення хребта - сколіоз - викликає порушення функціонування органів і систем. Якщо цей стан вчасно не діагностувати і не лікувати, то згодом відбуватиметься зміщення хребців, що може спричинити серйозні порушення в роботі внутрішніх органів і організму в цілому, що позначиться й на загальному самопочутті.

Аналіз різних медичних джерел, присвячених захворюванням хребта, в тому числі найсучасніших, дозволяє зробити висновок, що в більшості випадків причини появи сколіозу хребта залишаються невідомими.

До загальних причин викривлення хребта належать м'язові або кісткові зміни, адже для створення вертикальної осі хребта потрібно, щоб усі кістки і м'язи були строго симетричними. Часто сколіоз супроводжує інші захворювання опорнорухового апарату, нервової системи, системні захворювання сполучної тканини, що може мати як рефлекторний, так і психологічний характер [3].

Сколіоз призводить до розвитку анатомічних порушень, до яких належать сутулість і деформація грудної клітки. На ранніх стадіях розвитку захворювання ці зміни малопомітні, а зі збільшенням давності хвороби зменшуються шанси на успіх у лікуванні. Організм, намагаючись відновити вертикальний баланс хребта, утворює додаткові викривлення $[4,5]$.

При розвитку сколіозу міжхребцеві диски зазнають високого тиску з одного боку і низького з іншого, внаслідок чого зміщуються у бік низького тиску, чим тільки посилюють наявну асиметрію. Міжхребцеві диски при зміщенні викликають подразнення нервових закінчень, які їх оточують, в тому числі й вегетативних, які регулюють обмінні процеси в різних органах і тканинах організму, що призводить до розвитку кардіалгії, порушення функції жовчного міхура тощо.

Залежно від локалізації викривлення хребта розрізняють кілька видів сколіозу [2]: верхньогрудний, грудний, грудопоперековий, поперековий і комбінований сколіоз, при якому утворюється подвійне викривлення хребта. Залежно від величини кута викривлення виділяють IV ступені тяжкості сколіозу: при сколіозі I ступеня відхилення від осі становить 5-10 градусів, сколіоз ІІ ступеня характеризується вже більш вираженим відхиленням - до 30 градусів, сколіоз III ступеня - до 60 градусів і IV ступеня - більше 60 градусів.

Сколіоз хребта I ступеня можна діагностувати на підставі таких критеріїв: наявність перекосу тазових кісток, зведені і опущені плечі, постійно опущене положення голови, одне надпліччя вище іншого, намічається поворот хребців навколо своєї вертикальної осі, асиметрія талії. Для сколіозу II ступеня характерна наявність таких ознак: пово- 
Огляди літератури, оригінальні дослідження, погляд на проблему, випадок з практики, короткі повідомлення рот хребців навколо вертикальної осі, асиметрія контурів шиї й талії, на стороні викривлення в поперековому відділі може утворитися м'язовий валик, а в грудному відділі - випинання. При сколіозі III ступеня наявні усі ознаки сколіозу ІІ ступеня, а також виражена торсія і чітко окреслений реберний горб. Сколіозу IV ступеня притаманна виражена деформація хребта, а всі вищеописані симптоми посилені.

Окрім деформації хребта, реберних дуг, грудної клітки та зміщення лопаток, сколіоз призводить до ряду порушень у нервовій, серцево-судинній, сечостатевій, дихальній та ендокринній системах і шлунково-кишковому тракті.

З 2002-2004 до 2015-2016 років кількість пацієнтів віком від 8 до 14 років з чітким II та III ступенями сколіозу збільшилося фактично вчетверо, що свідчить про важливість вказаної проблеми [1]. Для ії̈ вирішення щорічно з'являються нові методики лікування та корекції деформації, відкривається чимало приватних центрів та кабінетів, які спеціалізуються на роботі з дітьми різного віку та з різними ступенями деформації хребта.

Мета - опис роботи з дітьми вікової групи від 9 до 16 років, які мають набутий сколіоз 2-го ступеня, міопатичного, нейрогенного та посттравматичного походження, впливу методик, які застосовують, на

кінцевий результат, а саме, на різницю в ступенях деформації в градусах (на рентгенівському знімку) та візуальні зміни (за антропометричними даними).

Матеріал і методи дослідження. Весь комплекс роботи з пацієнтом можна умовно поділити на 3 основних етапи.

ЕТАП 1. Діагностика.

На початку роботи потрібно визначити вихідні дані, щоб мати змогу фіксувати зміни, які відбуваються в процесі реабілітації та лікування. Визначають такі параметри:

1. Вік, зріст та вага пацієнта;

2. Кут деформації в градусах (на рентгенівському знімку);

3. Відхилення в бік відносно прямої осі, проведеної від атланта до куприка;

4. Рівень плечей, нижній край лопаток, таза, вертлюгів (рис. 1);

5. Наявність анатомічного та функціонального сегментарного вкорочення нижніх кінцівок;

6. Наявність вроджених патологій (дисплазія кульшових суглобів, дисплазія сполучної тканини, клишоногість тощо);

7. Наслідки після травм та хірургічного втручання (переломи, вивихи, металоостеосинтез);

8. Спадковість (наявність проблем з опорноруховим апаратом у батьків);
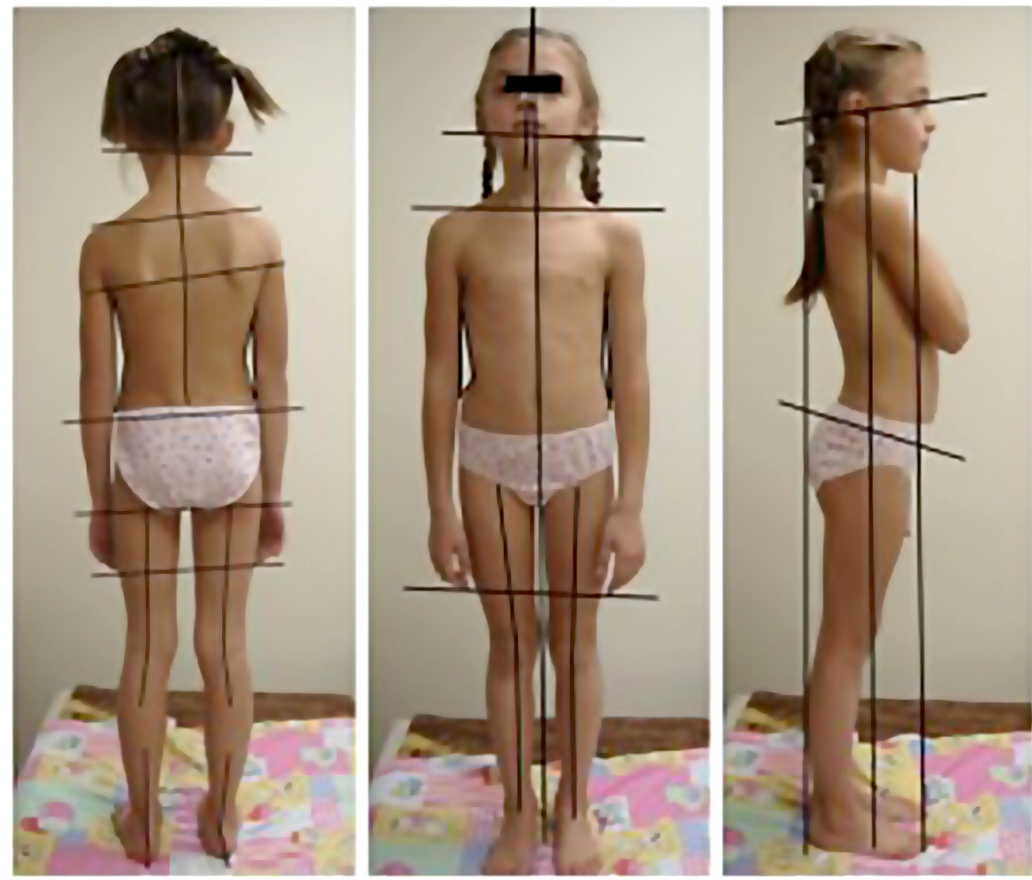

Рис. 1. Діагностика деформації хребта у фронтальній та сагітальній площинах.

ЕТАП 2. Основний результат досягається за допомогою 2 елементів.

Масаж (загальний оздоровчий та класичний лікувальний). При проведенні цієї процедури з само- го початку виділяють основні проблемні ділянки. Зазвичай це чітко виражений гіпертонус та гіпотонус м'язів спини. Основна робота проводиться з ними, адже для корекції положення хребта потрібно усу- 
Огляди літератури, оригінальні дослідження, погляд на проблему, випадок з практики, короткі повідомлення нути причину патологічного положення, а без нормальної роботи м'язів цього домогтися неможливо.

Фізична реабілітація. Індивідуально для кожного пацієнта підбирається комплекс вправ, які спрямовані на зміну патологічного положення, нормалізацію роботи м'язів та напрацювання м'язової пам'яті. Саме завдяки виконанню вправ

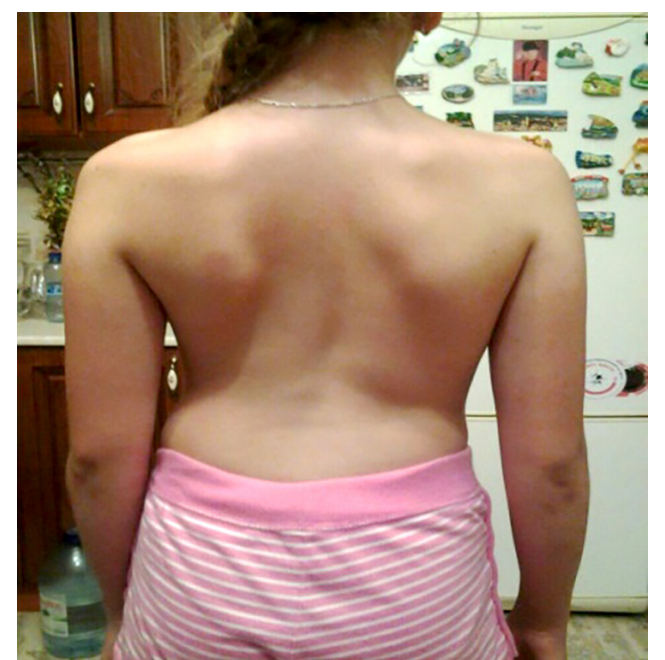

Рис. 2. До корекції сколіозу.

ЕТАП 3. Додатковими методами корекції сколіозу для дімей такого віку $\epsilon$ :

- Плавання;

- Кінезіотерапія;

- Ударно-хвильова терапія;

- Парафінотерапія та електрофорез.

Ці методи застосовують у тих випадках, коли позитивна динаміка виправлення деформації сповільнюється або зупиняється зовсім. Усі діти реагують на корекцію по різному, тому часто після фази активного прогресу та виправлення ско- м'язовий корсет починає утримувати правильне фізіологічне положення хребта та запобігає рецидиву деформації.

У більшості випадків, при якісному виконанні, цих методів лікування достатньо, щоб отримати позитивний результат та домогтися корекції в 1012 градусів за 2-3 місяці.

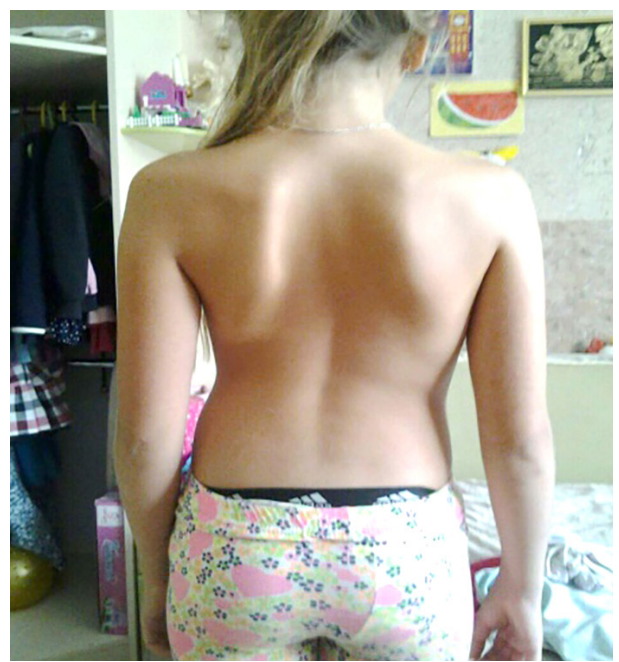

Рис. 3. Після трьох місяців корекції сколіозу з використанням фізичної реабілітації та масажу.

ліозу настає звикання організму до таких навантажень, тому для отримання кращого результату необхідний невеликий позитивний стрес.

Окрім видимих візуальних порушень постави, пацієнти мають декілька характерних скарг, які потрібно враховувати при роботі з ними:

1. Регулярні та постійні головні болі;

2. Запаморочення при зміні статичного положення;

3. Проблеми з травленням;

4. Задишка та аритмія;

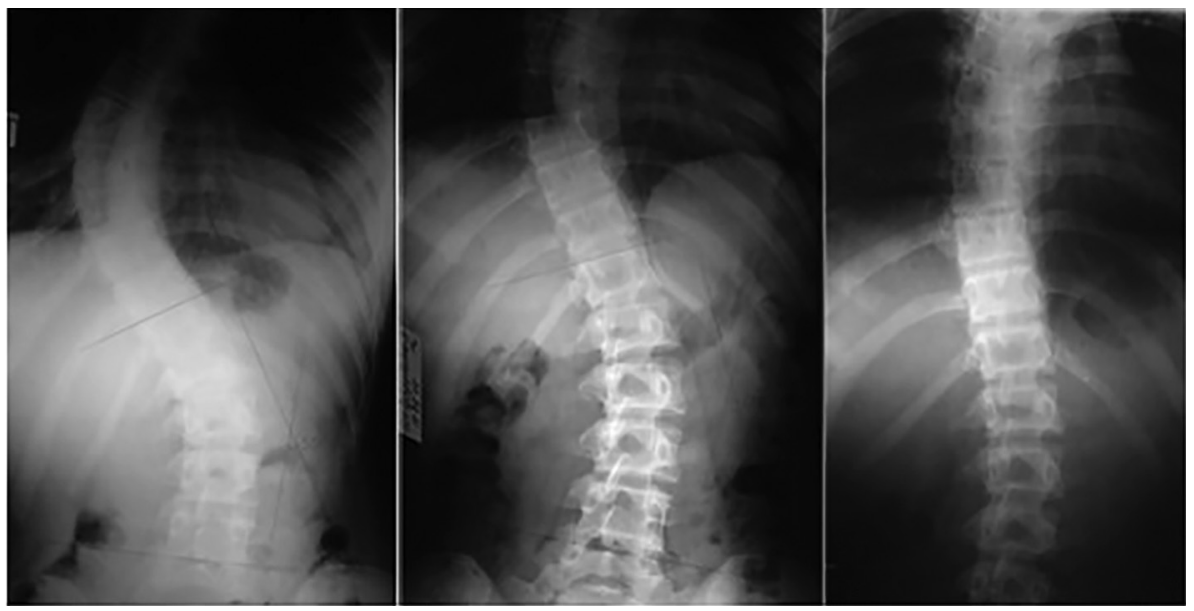

Рис. 4. Зміни хребта після трьох місяців корекції сколіозу з використанням фізичної реабілітації та масажу (рентгенограма). 
Огляди літератури, оригінальні дослідження, погляд на проблему, випадок з практики, короткі повідомлення

5. Постійні больові відчуття в спині (поперековий та грудний відділи);

6. Поганий сон;

7. Неможливість переносити фізичні навантаження.

При цьому основними завданнями є:

1. Усунути проблеми, пов'язані з больовими відчуттями;

2. Зменшити до максимально можливого рівня асиметрію в роботі м'язів;

3. Підготувати пацієнта до нормального сприйняття та перенесення фізичних навантажень;

4. Напрацювати м'язову пам'ять та розвинути м'язовий корсет для запобігання прогресуванню та зміщенню кута деформації хребта в більшу сторону.

Результати й обговорення. Метою була корекція мінімум на 10 градусів та закріплення отриманого результату.

У роботі з дітьми від 9 до 16 років виділяють декілька нюансів, які обов'язково потрібно враховувати при плануванні подальшої роботи.

1. Процес корекції хребта у них (на 10 градусів) при застосуванні методик, які були наведені вище в дітей 9-12 років, триває від 3 до 6 місяців. При цьому зріст дитини також збільшується на 4-8 см, деформація візуально стає майже непомітною (рис. 2, 3). У цій віковій групі не було необхідності застосовувати додаткові методи корекції для досягнення поставленої мети, проте для запобігання подальшому прогресуванню захворювання і закріплення результату ми рекомендували плавання, хвильову терапію, кінезіотерапію. Найкращий результат було досягнуто при застосуванні плавання (50 \%), ударно-хвильової терапії (20\%), кінезіотерапії (30\%), яку через алергічні реакції або слабкість імунітету пацієнта призначали замість плавання.

\section{ЛІТЕРАТУРА}

1. Авраменко О. М. Механотерапія у відновному лікуванні хворих на остеохондроз попереково-крижового відділу хребта / О. М. Авраменко // Слобожанський науково-спортивний вісник : [наук.-теор. вісн.] Харків : ХДАФК, 2013. - № 5. - С.16-18.

2. Зайцев В. П. Влияние комплексной психокореляции на динамику болевого синдрома и психологический статус больных остеохондрозом позвоночника / [В. П. Зайцев, О. Г. Тюрина, Т. А. Айвазян] // Терапевт. арх. - 2003. - T. 75, № 8. - С. 55-58.

3. Мухін В. М. Фізична реабілітація / В. М. Мухін. К : Олімпійська Література, 2000-424 с.
2. Для корекції викривлення хребта на 10 градусів у дітей віком від 12 до 14 років необхідно від 4 до 6 місяців. Проте обов'язково потрібно змінювати вид фізичної реабілітації кожні 40-60 днів, щоб запобігти звиканню організму. Окрім того, 16 з 20 дітей мали кращу динаміку виправлення деформації при застосуванні ударно-хвильової терапії та плавання (корекція на 12-14 градусів), а 4 не відреагували на додаткові засоби лікування.

3. Найдовше процес корекції триває в дітей віком від 14 до 16 років (через відповідні фізіологічні та анатомічні чинники). Окрім того, психологічно ця вікова група переносить процес лікування тяжче, ніж дві попередніх. Не всі дотримуються даних їм рекомендацій та тільки 30 \% (6 дітей) виконують повністю програму фізичної реабілітації вдома. Для корекції на 10 градусів потрібно від 6 до 12 місяців. Застосування кінезіотерапії, ударно-хвильової терапії та плавання при цьому $\epsilon$ обов'язковими у 90 \% дітей.

Висновки. Спостерігаючи за результатами корекції сколіозу у дітей з використанням ЛФК та масажу можна зробити висновок, що попри виникнення нових методик, засобів та винаходів для лікування даної проблеми, вказані засоби фізичної реабілітації залишаються основними та найефективнішими. Головне, щоб кваліфікація спеціалістів, які працюють з дітьми, була відповідною. Ми не можемо відкидати такі методи корекції як ортезування хребта чи апаратні витяжки, проте, за даними статистики та нашими спостереженнями, в роботі з пацієнтами на сьогодні ефективніших засобів, які 6 забезпечували уникнення рецидиву або виникнення побічних ефектів, немає.

Перспективи подальших досліджень полягають в досягненні за допомогою таких же методів кращих результатів. Тобто, за основу в подальшому ми будемо брати корекцію в 12-16 градусів за той самий проміжок часу. 
Огляди літератури, оригінальні дослідження, погляд на проблему, випадок з практики, короткі повідомлення

7. Finsterer J. Familial, long-term pollakisuria as initial manifestation of HSP4 due to the SPAST variant / J. Finsterer, S. M. Wakil, F. Laccone / J. Clin. Neurosci. - 2019. No. 5. DOI: 10.1016/j.jocn.2019.03.067.

8. Garg N. Scheuermann's Disease with Extensive Involvement of Dorsolumbar Spine / N. Garg, N. Gupta, D. Shah // Indian. J. Pediatr. - 2018. - No. 85(9). - P. 818-819.
DOI: 10.1007/s12098-018-2675-3.

9. Minimum ten-year follow-up of spinal stenosis with degenerative spondylolisthesis treated with decompression and dynamic stabilization / Kotryna Veresciagina, Arne Mehrkens, Stefan Schären, Bernhard Jeanneret // Jornal of Spine Surgeri. - 2018. - Vol 4, No 1. - P. 93-101.

\section{REFERENCES}

1. Avramenko, O.M. (2013). Mekhanoterapiia u vidnovnomu likuvanni khvorykh na osteokhondroz poperekovo-kryzhovoho viddilu khrebta [Mechanotherapy in restorative treatment of patients with osteochondrosis of the lumbar-sacral division of the spine]. Slobozhanskyi naukovo-sportyvnyi visnyk: [nauk.-teor. visn.] - Slobozhanskyi Scientific and Sport Bulletin: [Sci.-theory. Bulletin.], 5, 16-18 [in Ukrainian].

2. Zaytsev, V.P., Tyurina, O.G., \& Ayvazyan, T.A. (2003). Vliyaniye kompleksnoy psikhokorelyatsii na dinamiku bolevogo sindroma i psikhologicheskiy status bolnykh osteokhondrozom pozvonochnika [Influence of complex psychocorrelation on the dynamics of pain syndrome and psychological status of patients with osteochondrosis of the spine]. Terapevt. arkh. - Therapeutical Archieve, 75, 8, 55-58 [in Russian].

3. Mukhin, V.M. (2000). Fizychna reabilitatsiia [Physical rehabilitation]. Kyiv: Olimpiiska Literatura [in Ukrainian].

4. Yepifanov, V.A., Rolyk, I.S., \& Yepifanov, A.V. (2000). Osteokhondroz khrebta [Osteochondrosis of the spine]. Moscow: ZAT "Akademichnyi drukarskyi dim" [in Ukrainian].

5. Peshkova, O.V., \& Zhenzy, K. (2004). Kompleksnaya fizicheskaya reabilitatsiya bolnykh poyasnichno-kresttso- vym osteokhondrozom pozvonochnika [Comprehensive physical rehabilitation of patients with lumbosacral spinal osteochondrosis]. Slobozhanskyi naukovyi visnyk - Slobozhanskyi Scientific Bulletin, 7, 168-170 [in Russian].

6. Lazarev, I.A. (2002). Kinezoterapiya na naklonnoy ploskosti pri nevrologicheskikh proyavleniyakh poyasnichnogo otdela pozvonochnika [Kinesitherapy on an inclined plane with neurological manifestations of the lumbar spine]. Ukr. med. chasopis. - Ukrainian Medical Chronicle, 2, 41-46 [in Russian].

7. Finsterer, J., Wakil, S.M., \& Laccone, F. (2019). Familial, long-term pollakisuria as initial manifestation of HSP4 due to the SPAST variant. J. Clin. Neurosci., 5. DOI: 10.1016/j. jocn.2019.03.067.

8. Garg, N., Gupta, N., \& Shah, D. (2018). Scheuermann's disease with extensive involvement of dorsolumbar spine. Indian. J. Pediatr., 85 (9), 818-819. DOI: 10.1007/ s12098-018-2675-3.

9. Veresciagina, K., Mehrkens, A., Schären, S., Jeanneret, B. (2018). Minimum ten-year follow-up of spinal stenosis with degenerative spondylolisthesis treated with decompression and dynamic stabilization. Jornal of Spine Surgery, 4 (1), 93-101.

\title{
МАССАЖ И ЛЕЧЕБНАЯ ФИЗИЧЕСКАЯ КУЛЬТУРА КАК СРЕДСТВА ФИЗИЧЕСКОЙ РЕАБИЛИТАЦИИ ПРИ РАЗНОВИДНОСТЯХ СКОЛИОЗА У ВЗРОСЛЫХ И ДЕТЕЙ С НАРУШЕНИЯМИ ОПОРНО-ДВИГАТЕЛЬНОГО АППАРАТА
}

\author{
○Н. А. Давибида, Д. В. Попович, Н. М. Беспалова, А. М. Довгань, \\ В. Б. Коваль, А. В. Вайда, Ю. М. Черний
}

Тернопольский национальный медицинский университет имени И. Я. Горбачевского МОЗ Украины

РЕЗЮМЕ. Сколиоз приводит к развитию анатомических нарушений. Трудность состоит в том, что сколиоз на ранних стадиях развития заболевания может быть малозаметен, а увеличение длительности болезни приводит к уменьшению шансов на успех в лечении. Организм, пытаясь восстановить вертикальный баланс позвоночника, образует дополнительные искривления.

Цель - описание методик работы с детьми возрастной группы от 9 до 16 лет с приобретенным сколиозом 2-й степени и их влияние на конечный результат, а именно, на разницу в степенях деформации в градусах (на рентгеновском снимке) и визуальные изменения (по антропометрическим данным).

Материал и методы. Использованы методы диагностики и физической реабилитации для коррекции сколиоза различной степени при лечении детей 6-12 лет с указанной патологией

Результаты. При развитии сколиоза межпозвонковые диски испытывают влияние высокого давления с одной стороны и низкого - с другой, в результате чего смещаются в сторону низкого давления, чем только 
Огляди літератури, оригінальні дослідження, погляд на проблему, випадок з практики, короткі повідомлення усиливают имеющуюся асимметрию. Межпозвонковые диски вызывают раздражение окружающих нервных окончаний, в том числе и вегетативных, регулирующих обменные процессы в различных органах и тканях организма, что приводит к развитию кардиалгий, нарушению функций желчного пузыря и тому подобное.

КЛючЕВЫЕ СЛОВА: сколиоз; опорно-двигательный аппарат; физическая реабилитация; массаж.

\title{
MASSAGE AND THERAPEUTIC PHYSICAL TRAINING AS A PHYSICAL REHABILITATION FOR DISEASES OF SKOLIOSIS IN ADULTS AND CHILDREN WITH MUSCLE-SKELETON DISORDERS
}

\author{
@N. O. Davybida, D. V. Popovich, N. M. Bezpalova, O. M. Dovgan,
}

V. B. Koval, O. V. Vayda, Yu. M. Chernyi

\section{Horbachevsky Ternopil National Medical University}

SUMMARY. Scoliosis leads to the development of anatomical disorders. The difficulty lies in the fact that scoliosis in the early stages of the disease may not be noticeable, and an increase in the duration of the disease leads to a reduction in the chances of success in the treatment. The body, trying to restore the vertical balance of the spine, forms additional distortion.

The aim - to describe the methods of working with children from the age group of 9 to 16 years old with acquired grade 2 scoliosis and their effect on the final result, namely, the difference in degree of deformation in degrees (on an $\mathrm{X}$-ray) and visual changes (according to anthropometric data).

Material and Methods. Used methods of diagnostics and physical rehabilitation for the correction of scoliosis of different degrees in the treatment of children aged from 6 to 12 years with the specified pathology.

Results. In the development of scoliosis, the intervertebral discs undergo high pressure on one side and low - on the other, resulting in being displaced in the direction of low pressure, rather than increasing the existing asymmetry. Intervertebral discs cause irritation of surrounding nerve endings, including vegetative, which regulate metabolic processes in various organs and tissues of an organism, which leads to cardialgia development, impaired functions of the gallbladder, and the like.

KEY WORDS: scoliosis; musculoskeletal system; physical rehabilitation; massage. 